Z Badań nad Książką i Księgozbiorami Historycznymi 2020, t. 14, z. 2

The Studies into the History of the Book and Book Collections 2020, vol. 14, no. 2

www.bookhistory.uw.edu.pl

Grażyna Lewandowicz-Nosal

Biblioteka Narodowa, Warszawa

grazyna.lewandowicz@poczta.onet.pl

(iD) 0000-0002-4655-7053

\title{
„Trzy kobiety i biblioteka”. Warszawska Biblioteka Wzorowa dla dzieci i jej kierowniczki (1927-2004) ${ }^{1}$
}

\author{
“Three women and a library". The Warsaw Model Library for \\ Children and its managers (1927-2004)
}

\begin{abstract}
The Warsaw Model Library for Children, opened in Warsaw in November 1927, is one of the best-known institutions of this type in Poland. Its organization and methods of work have served, according to the name, as an organizational model of other children's libraries. However, the library is not only a place and collections but also people - librarians. The article presents the characters of three managers of this library and their contribution to the development of such a single institution and its impact on the nationwide network of public libraries for children. The character and activity of the organizer and the first manager of the library Maria Gutry, then Zofia Wędrychowska-Papuzińska, and Sława Łabanowska, a long-time first post-war library manager, will be discussed. The fate of the library itself is the background to present their activity. The available biographical materials and archival documents collected in the library will be referred to.
\end{abstract}

Key words: the Warsaw Model Library for Children - Warsaw - Maria Gutry - Zofia Wędrychowska-Papuzińska - Sława Łabanowska - 1927-2004.

Słowa kluczowe: Biblioteka Wzorowa dla dzieci - Warszawa - Maria Gutry - Zofia Wędrychowska-Papuzińska - Sława Łabanowska - 1927-2004.

1 Daty wyznaczone powstaniem biblioteki w 1927 r. oraz śmiercią Sławy Łabanowskiej, wieloletniej powojennej kierowniczki placówki.

„Z Badań nad Książką i Księgozbiorami Historycznymi” - Udział zagranicznych recenzentów w ocenie publikacji; Stworzenie anglojęzycznej wersji wydawniczej publikacji; Digitalizacja tomów archiwalnych rocznika w celu zapewnienia otwartego dostepu do nich przez Internet oraz wdrożenie i utrzymanie cyfrowej platformy redakcyjnej - zadanie finansowane w ramach umowy nr 653/P-DUN/2019 ze środków Ministra Nauki i Szkolnictwa Wyższego przeznaczonych na działalność upowszechniającą naukę. 


\section{Wstęp}

Tym, co wyróżnia biblioteki publiczne dla dzieci spośród innych placówek jest przede wszystkim czytelnik, a ponadto: specjalnie kompletowane zbiory, prowadzenie różnych form pracy, których celem jest popularyzacja czytelnictwa oraz kompetencje bibliotekarza pracującego z dziećmi i młodzieżą.

Dziś wiele mówi się o bibliotekach bez bibliotekarzy ${ }^{2}$, jednak uważam, że w przypadku pracy z najmłodszym czytelnikiem osoba bibliotekarza jest niezbędna. Powód jest prosty - dziecko potrzebuje dorosłego przewodnika na drodze rozwoju, w tym podczas wyboru książek do czytania. Przypomnijmy, że bibliotekarz dziecięcy ma do czynienia z czytelnikiem u progu swojej kariery bibliotecznej, czytelnikiem, który nie zawsze wie czy chce czytać i co chce czytać. Często nie wie, że są biblioteki specjalnie dla niego przeznaczone i co może w nich znaleźć. Skuteczne zachęcanie dzieci i młodzieży do przyjścia do placówki to chyba jedno z najważniejszych zadań, zwłaszcza współczesnego, bibliotekarza.

Joanna Papuzińska pisała, że biblioteczna praca z dziećmi jest szczególnym przywilejem. Daje świadomość, że jest ważną inwestycją dla przyszłości samych dzieci, bibliotek i zawodu bibliotekarskiego:

Kiedy obsługujemy dziecko widzieć w nim trzeba przyszłego użytkownika biblioteki naukowej, wojewódzkiej, miejskiej, dostrzegać przyszłego radnego, ojca miasta, który będzie przydzielał fundusze dla biblioteki, decydował o ich bogactwie albo ubóstwie. Ten rodzaj pracy pozwala w pełni wykorzystać własne uzdolnienia i dyspozycje twórcze. Bibliotekarz nie przekazuje wiedzy, ale odpowiada na pytania, proponuje rozwiązania i reaguje na potrzeby dzieci3 ${ }^{3}$.

Warto mieć też na uwadze stereotyp bibliotekarzy, jaki funkcjonuje w świadomości młodych, którzy postrzegają ich między innymi jako obsesjonatów ciszy, nudnych sztywniaków, nieznających się na komputerach, kobiety w okularach z grubymi szkłami ${ }^{4}$. Nie istnieje niestety specjalność bibliotekarza dziecięcego na studiach bibliotekoznawczych ani w szkołach policealnych, dlatego bardzo ważne są spotkania i seminaria organizowane na terenie powiatu czy województwa, wymiana doświadczeń, samokształcenie. Podstawowe cechy i umiejętności bibliotekarza dziecięcego zostały określone w wytycznych

2 Zob. np. K. Boelt, Open libraries in Aalborg - a great success, „Scandinavian Library Quarterly" 2015, Vol. 48, nr 1-2, [online] http://www.slq.nu/indexe9ab.html?article=volume-48-no-1-2-2015-19 [dostęp 12.06.2020]; C.G. Johannsen, Staffless libraries - recent Danish public libraries experiences, „New Library World” 2012, Vol. 113, nr 7/8, s. 333-342.

3 J. Papuzińska, Biblioteki w stużbie dzieciom, [w:] Biblioteka w otoczeniu społecznym, pod red. B. Zybert, Warszawa 2000, s. 76.

4 Więcej na ten temat $\mathrm{w}$ artykule M. Zająca, Biblioteki i młodzież: przyjaciele, wrogowie, nieznajomi?, [w:] Biblioteka w otoczeniu spolecznym, dz. cyt., s. 82. 
opracowanych przez Sekcję Bibliotek dla Dzieci i Młodzieży IFLA. Zwrócono w nich uwagę na to, że każda biblioteka powinna być

zarządzana przez profesjonalistów wspieranych przez specjalistów o różnych umiejętnościach zawodowych takich jak: dobra znajomość poszczególnych faz rozwoju dziecka, jego potrzeb edukacyjnych, mechanizmów zapoznawania z książką i lekturą, doskonałej znajomości dobrych książek dla dzieci, kompetencji w oferowaniu jak najlepszego miejsca pod względem wyposażenia dla małych dzieci i tych, którzy się nimi opiekują5.

Do pożądanych cech bibliotekarza dziecięcego należą m.in.: entuzjazm, komunikatywność, umiejętności interpersonalne, pracy zespołowej i rozwiązywania problemów

W swoich wspomnieniach ${ }^{7}$ J. Papuzińska opisywała pierwszy kontakt z bibliotekarką w bibliotece dla dzieci ${ }^{8}$. Była to „malutka pani w okularach” „podobna do dobrotliwej sowy"9. Była niezwykła - stwierdziło dziecko ${ }^{10}$. W czym się zawierała jej niezwykłość? Wydaje się, że przede wszystkim w powitaniu - bardzo indywidualnym - «Ach, więc to ty» ${ }^{11}$, pełnym zrozumienia i oczekiwania, połączonego z pewnością, że się tu, do biblioteki, przyjdzie. Każde dziecko jest w niej traktowane jako osoba, jednostka. Niezwykłość bibliotekarki polegała też na tym, że wstała od stolika i poprowadziła gościa „labiryntem regałów, opowiadając [...], gdzie jakie książki stoją i jak są oznaczone"12 to idealny przykład indywidualnego wprowadzenia dziecka przychodzącego pierwszy raz do biblioteki, obraz bibliotekarza, który z szacunku do swojego czytelnika wstaje, wychodzi zza biurka i razem ruszają w królestwo biblioteki.

Cichuteńkim, szemrzącym szeptem, takim przeznaczonym tylko dla mnie i dla nikogo więcej, wypytywała mnie, co czytam i co lubię, ja zaś od razu poczułam się zaprzyjaźniona z tą maleńką panią, bo miałyśmy wspólne upodobania i niechęci ${ }^{13}$.

Oto dalszy ciąg indywidualnej rozmowy mającej na celu poznanie przyszłego czytelnika, jego oczytania, znajomości książek, bardzo ważna pierwsza rozmowa o tym, co dziecko lubi a czego nie. Tu nawiązuje się pierwsze

5 Dzieci, młodzież - Internet - biblioteka. Wytyczne IFLA Sekcji Bibliotek dla Dzieci i Młodzie$\dot{z} y$, red. G. Lewandowicz-Nosal, E.B. Zybert, Warszawa 2009, s. 25.

6 Tamże, s. 56.

7 J. Papuzińska, Darowane kreski, wyd. 2, Łódź 2002.

8 Wspominaną bibliotekarką była Felicja Neubert (1904-1978), w latach 1946-1949 kierowniczka biblioteki dla dzieci nr $1 \mathrm{w}$ Warszawie przy ul. Pięknej 15 a następnie, do przejścia na emeryturę w 1970 r., kierowniczka Muzeum Książki Dziecięcej. Obszerny biogram F. Neubert autorstwa Ludmiły Pęskiej w: Entuzjastki bibliotekarstwa dziecięcego, [red. tomu B. Białkowska, przy współudz. W. Wasilewskiej], Warszawa 1999, s. 63-70.

9 J. Papuzińska, Biblioteka [fragmenty wspomnień z książki Darowane kreski, Łódź 2002], „Guliwer” 2005, nr 3, s. 34.

10 J. Papuzińska, Biblioteka, dz. cyt., s. 34.

11 Tamże.

12 Tamże.

13 Tamże. 
porozumienie między dzieckiem a bibliotekarzem, obie strony mają szansę się poznać, spotkać. Znowu o wadze tego pierwszego kontaktu, spotkania będzie wielokrotnie pisała w swoich pracach profesor Papuzińska. Zawsze rozmawiaj z czytelnikiem - to hasło realizowane przez pokolenia bibliotekarzy. Wtedy jest szansa, że książki, które będziesz proponować do przeczytania znajdą uznanie, a ty sam będziesz traktowany jak poważny specjalista, znawca i przyjaciel. Często rozmowy o książkach, o ich treści, to tylko wstęp do rozmów o życiu i jego problemach, szansa na dotarcie do świata dziecka i związanych z nim emocji. Dobry bibliotekarz to po prostu ten, który zawsze znajdzie czas na rozmowę z czytelnikiem.

Po tej rozmowie wprowadzającej, którą można traktować jako swoistą inicjację biblioteczną, ważny jest moment dalszej, samodzielnej już wędrówki dziecka po bibliotece, samodzielnego oswajania miejsca, przestrzeni:

ja wędrowałam sama w tę i z powrotem wzdłuż półek [...]. Wpatrywałam się w rzędy nazwisk wypisanych na kolorowych paskach płótna, przekrzywiając głowę czytałam tytuły, czasem wysuwałam książkę do połowy żeby zobaczyć okładkęę.

Obok zainteresowania u dziecka pojawił się też zachwyt, że tyle jest książek, że niektóre są znane, innych jest więcej niż się można było spodziewać ${ }^{15}$. Wyżej zacytowanymi słowami, „biblioteczne dziecko”, jak samą siebie określiła ${ }^{16}$, Papuzińska oddała hołd polskim bibliotekarkom dla dzieci, osobom niezwykłym, zaangażowanym w pracę, w kształcenie, ale może przede wszystkim w wychowywanie kolejnych pokoleń obywateli.

W dalszej części artykułu zaprezentowane zostaną postacie trzech kobiet, kierowniczek jednej z warszawskich bibliotek dla dzieci. Były niezwykłe, tak jak niezwykła była i jest placówka, którą tworzyły i kierowały: Warszawska Biblioteka Wzorowa. Nazwano ją ,wzorowa”, gdyż jej organizacja i metody pracy z najmłodszym czytelnikiem miały stanowić i stanowiły wzór dla powstawania kolejnych tego typu placówek w Polsce ${ }^{17}$.

14 Tamże, s. 35 .

15 Na ten temat zob. G. Lewandowicz-Nosal, Biblioteka dla dzieci: miejsce magiczne, [w:] Ocalone królestwo. Twórczość dla dzieci-perspektywy badawcze-problemy animacji, red. nauk. G. Leszczyński, D. Świerczyńska-Jelonek, M. Zając, Warszawa 2009, s. 315-317.

16 J. Papuzińska, Biblioteka, dz. cyt., s. 34.

17 Zob. Biblioteki dla dzieci w Polsce, Warszawa 1934; H. Langer, Obraz Biblioteki Wzorowej na łamach periodyków Biblioteki Publicznej m.st. Warszawy (1929-1939), „Bibliotheca Nostra” 2016, nr 3(45), s. 73-85; G. Lewandowicz-Nosal, Public libraries for children in Poland 1918-1939 - assumptions and reality, „Z Badań nad Książką i Księgozbiorami Historycznymi” 2019-2020, t. specjalny: Dla Niepodległej, red. nauk. tomu M. Ochmański, D. Pietrzkiewicz, J. Puchalski, s. 5372. Na wzór warszawskiej placówki zorganizowano m.in. biblioteki w Toruniu, Krakowie, zob. tamże. 


\section{Biblioteka Wzorowa dla Dzieci}

Oprócz trzech kierowniczek, Marii Gutry, Zofii Wędrychowskiej-Papuzińskiej i Sławy Łabanowskiej, których krótkie biogramy zostaną zaprezentowane w dalszej części artykułu, bohaterką niniejszego opracowania jest Biblioteka Wzorowa dla dzieci, Biblioteka dla Dzieci nr 1, Biblioteka dla Dzieci nr V, Biblioteka dla Dzieci nr 5. Pod tymi wszystkimi nazwami, tytułami, numerami kryje się ta sama placówka działająca od 90-ciu lat, z krótką okupacyjną przerwą, na warszawskiej Ochocie. Jej historia jest dobrze znana i opisana w literaturze przedmiotu $^{18}$, dlatego należy tu przypomnieć kilka podstawowych faktów ${ }^{19}$.

Helena Radlińska zaproponowała, aby na IV Wystawie Księgarskiej zorganizowanej przez Związek Księgarzy i Wydawców Polskich w dniach 1-7 XI 1926 r. zaprezentowano zorganizowany księgozbiór, eksponowany jako „Biblioteka Wzorowa dla dzieci”. Do zbioru dołączono obejmujący 100 stron katalog mający ułatwić kompletowanie księgozbiorów w bibliotekach szkolnych i dziecięcych ${ }^{20}$. Po zamknięciu wystawy Związek przekazał księgozbiór Towarzystwu Biblioteki Publicznej m.st. Warszawy z warunkiem, aby uruchomiono taką bibliotekę dla dzieci. Otwarto ją rok później, 25 XI 1927 r. na warszawskiej Ochocie a przeznaczona była dla wszystkich dzieci w wieku od 7 do 12 lat. Wzorem organizacyjnym dla tej placówki, jej struktury wewnętrznej i metod pracy, stała się paryska biblioteka „L'Heure Joyeuse”. Maria Gutry, która objęła kierownictwo Biblioteki Wzorowej, pisała:

głównym celem biblioteki jest bezpłatne udostępnienie niezamożnym dzieciom przedmieścia dobrej książki rozrywkowej lub uzupełniającej naukę. Cel uboczny - to zbliżenie dzieci do książek przez wolny dostęp do półek z prawem dobrowolnego wyboru, umożliwienie korzystania z katalogów różnego typu, w atmosferze samorzutnie wytwarzającej się ciszy. Są to wszystko czynniki, które działają wychowawczo, podnosząc kulturę przez umiejętność obcowania z książką i jej użytkowania ${ }^{21}$.

Placówka była filią Biblioteki Publicznej m.st. Warszawy. Zadania, jakie jej postawiono to: skompletowanie całokształtu literatury dla dzieci i młodzieży; opracowanie wskazówek dotyczących organizacji bibliotek tego typu; sprawdzenie metod pracy stosowanych w bibliotekach zagranicznych i wypracowanie własnych; przyjmowanie praktykantów; prowadzenie badań nad czytelnictwem dzieci oraz sporządzanie bibliografii z zakresu bibliotek i literatury dziecięcej. Książki, których liczba dzięki przysługującemu egzemplarzowi

18 Zob. m.in. M. Gutry, Biblioteka wzorowa dla dzieci m.st. Warszawy, [w:] Biblioteki dla dzieci..., s. 9-14.

19 G. Lewandowicz-Nosal, Public libraries..., s. 53-72.

20 J. Filipkowska-Szemplińska, M. Gutry, Katalog biblioteki wzorowej dla dzieci i młodzieży, z przedmową H. Radlińskiej, Warszawa 1927, s. 127.

21 M. Gutry, Biblioteka wzorowa..., s. 9. 
obowiązkowemu szybko rosła, zostały ułożone działami. Do porządkowania wydawnictw popularnonaukowych zastosowano klasyfikację dziesiętną. Stopniowo wypracowywano w bibliotece różne formy pracy z książką i czytelnikiem. Dla najmłodszych były to opowiadania baśni, głośne czytanie. Starszych zapraszano na odczyty, przeprowadzano liczne konkursy. Dzieci sporządzały albumy albo pisały swoje opinie o książkach w zeszycie „recenzje”. W roku 1933/1934 zapoczątkowano pogadanki o sposobach korzystania z książek i pomocy bibliotecznych przy odrabianiu lekcji. Regulamin czytelni składał się z czterech punktów: 1. myć ręce przed czytaniem, 2. szanować książki, 3. dbać o ciszę, 4. nie przychodzić do biblioteki, gdy ktoś w domu jest chory. Wychodząc z biblioteki, dzieci zaznaczały swą obecność wrzucając do pudełka kolorowy krążek w zależności od płci - żółty lub niebieski. Były to przepisy dla tzw. czytelników-gości, natomiast dzieci przychodzące do biblioteki częściej, włączające się w różne prace, zostawały tzw. stałymi czytelnikami. Mogły wówczas odkładać na następny dzień książkę do przeczytania, pełnić dyżury, pomagać bibliotekarce w pracy. Stali czytelnicy mieli swoje karty, na których notowano ich wybory lekturowe. Raz w miesiącu odbywały się zebrania stałych czytelników, na których omawiano działania z poprzedniego miesiąca i ustalano plan pracy na następny.

W styczniu 1933 r. przy czytelni została uruchomiona wypożyczalnia dla dzieci, bez wolnego dostępu do półek. Prace biblioteczne prowadzone były przez skromną obsadę $\mathrm{w}$ wymiarze $1 \frac{1}{2}$ etatu z pomocą praktykantek z Rocznej Szkoły Bibliotekarskiej przy Bibliotece Publicznej oraz ze Studium Pracy Społeczno-Oświatowej Wolnej Wszechnicy Polskiej (WWP). W 1935 r. biblioteka została przeniesiona do samodzielnego lokalu przy ul. Reja $9^{22}$ i stała się Biblioteką dla Dzieci nr 1, co było spowodowane utworzeniem w Warszawie jednej sieci bibliotek obsługujących dzieci.

Zamknięta we wrześniu 1939 r. podczas działań wojennych, wznowiła pracę w grudniu tego roku i była otwarta do sierpnia 1942 r., kiedy decyzją władz niemieckich zamknięto wszystkie biblioteki w okupowanej stolicy.

Po wojnie, już jako Biblioteka dla Dzieci nr V rozpoczęła swoją działalność 1 X 1946 r. w na wpół wypalonym gmachu obecnego Liceum Ogólnokształcącego im. H. Kołłątaja, w swojej pierwszej siedzibie (ul. Grójecka 93). Numer V oznaczał, że była to piąta biblioteka dla dzieci uruchomiona po wojnie ${ }^{23}$ - cyframi rzymskimi oznaczano biblioteki dla dzieci w odróżnieniu od numeracji bibliotek dla dorosłych. Obecnie jest to Biblioteka nr 5; po prostu ,piątka”. Po dawnej numeracji rzymskiej nie ma śladu. Symbolicznie można powiedzieć, że cały czas jest to biblioteka wzorowa - na ,piątkę".

\footnotetext{
22 Obecnie w tym budynku mieści się Teatr Ochoty.

23 Z. Umerska, Pani Staweczka (1926-2004), „Poradnik Bibliotekarza” 2004, nr 7-8, s. 47.
} 
W następnych dziesięcioleciach placówka kilkakrotnie zmieniała swoją lokalizację. W 1956 r. otrzymała lokal na ul. Częstochowskiej 26, w 1971 r. odbyła się kolejna przeprowadzka na ul. Skarżyńskiego 5, wreszcie w listopadzie 1985 r. na Grójecką 81/87. Ostatnia przeprowadzka miała miejsce w 2011 r. kiedy placówka uzyskała dwupoziomowy lokal po dawnej księgarni na ul. Grójeckiej 109 w tzw. pawilonie „pod skrzydłami”.

W 1994 r., po latach starań, bibliotece nadano imię Z. Wędrychowskiej-Papuzińskiej. $19 \mathrm{~V} 1994$ r. odsłonięto tablicę pamiątkową z napisem:

Pamięci Zofii Wędrychowskiej-Papuzińskiej 1905-1944 / wybitnego pedagoga, bibliotekarza, społecznika / kierownika Wzorowej Biblioteki dla Dzieci na Ochocie w latach 19351942 / w 50 rocznicę śmierci na Pawiaku w dniu 26.IV.1944.

Jej zasługą w rozwijaniu placówki było m.in. stworzenie aktywu bibliotecznego, umiejętność współpracy z grupą młodych przyjaciół biblioteki zrzeszonych w Kole Stałych Czytelników. W jej pracy bibliotekarskiej odcisnął się wpływ wychowania korczakowskiego.

Przez wszystkie lata działalności biblioteki rozwijano nie tylko księgozbiór, ale przede wszystkim różnorodne formy pracy z czytelnikiem. Początkowo były to formy nastawione na słowo mówione - opowiadanie baśni, głośne czytanie, teatrzyki. W latach 60. i 70. XX w. za sprawą S. Łabanowskiej rozwinęły się kursy wiedzy o Warszawie - przy bibliotece działała Komisja Młodzieżowa Towarzystwa Przyjaciół Warszawy (TPW) Oddziału Ochota. Łabanowska prowadziła również zajęcia dla dzieci chorych, niepełnosprawnych, praktycznie realizując nieznaną jeszcze na szerszą skalę w latach 60-70. ubiegłego wieku biblioterapię. W kolejnych dekadach pracę z czytelnikiem zdominowały lekcje biblioteczne, ale ponownie za sprawą S. Łabanowskiej prowadzone w sposób aktywizujący, z wykorzystaniem indywidualnych i zespołowych kart pracy.

Kontynuując przedwojenne tradycje także dziś biblioteka dysponuje bardzo bogatym księgozbiorem, utrzymano również tradycje szkoleń i staży dla studentów - przede wszystkim studiów pedagogicznych i bibliotekoznawczych. Nadal jest placówką nowoczesną, stanowiącą warsztat pracy dla innych bibliotekarzy, w której testowane są różne formy pracy z czytelnikiem. Natomiast, ze względu na dużą liczbę czytelników zrezygnowano z prowadzenia badań czytelnictwa dzieci. Jej obecna kierowniczka, Ewa Wasilewska, napisała: „Biblioteka miała szczęście do wielkich osobowości bibliotekarstwa dziecięcego ${ }^{24}$. I rzeczywiście tak było. Pierwszą z nich była nestorka polskiego bibliotekarstwa dziecięcego M. Gutry.

24 E. Wasilewska, Stawa Zofia Labanowska (1926-2004), [w:] Bibliotekarze Warszawscy zmarli w latach 1997-2007, red. tomu M. Lenartowicz, Warszawa 2010, s. 127. 


\section{Maria Gutry (1899-1988)}

Ktoś, komu się udało - tak swoje wspomnienie o M. Gutry zatytułowała Halina Skrobiszewska ${ }^{25}$. I chyba rzeczywiście tak było.

Niestrudzona organizatorka polskiego bibliotekarstwa dziecięcego (zarówno przed wojną jak i w okresie powojennym) i mistrzyni w trudnym zawodzie wychowania młodych użytkowników i miłośników książek ${ }^{26}$.

Niewysoka, o pięknych czarnych oczach, skromnie, ale gustownie ubrana - tak ją zapamiętała Elżbieta Biegajówna ${ }^{27}$. Autorka wspomnienia charakteryzowała M. Gutry jako osobę rzetelną, odpowiedzialną, o promieniującej osobowości, pełną autentyzmu i zaangażowania, mówiącą prosto i z przekonaniem. Skromna, życzliwa, doskonały organizator - wspominała Krystyna Kuźmińska ${ }^{28}$.

M. Gutry urodziła się w Warszawie w 1899 r. W latach 1925-1927 ukończyła trzyletnie Studium Pracy Społeczno-Oświatowej WWP założone i prowadzone przez H. Radlińską. Wspólnie ze swoją mistrzynią przygotowała katalog książek Biblioteki Wzorowej dla dzieci na IV Wystawę Księgarską w 1926 r. W listopadzie 1927 r. została pierwszą kierowniczką tej placówki. Wiele uwagi poświęcała starannemu doborowi księgozbioru, który miał wspomagać proces wychowania i rozwoju wewnętrznego małych czytelników. Wspólnie z innymi bibliotekarkami oceniała i selekcjonowała książki wpływające do placówki jako egzemplarze obowiązkowe. Nie wszystkie nadawały się do biblioteki. Paradoksalnie, książki odrzucone w trakcie selekcji stanowiły zalążek zbioru późniejszego Muzeum Książki Dziecięcej, którego M. Gutry również była organizatorką. Dzięki swojemu zaangażowaniu i wiedzy została powołana w skład Komisji Oceny Książek dla Młodzieży w MWRiOP, razem z Marią Arnoldową i Barbarą Groniowską. Działaniom związanym z oceną publikacji towarzyszyło jej zainteresowanie czytelnictwem dzieci. Na podstawie założonych czytelnikom Biblioteki Wzorowej analitycznych kart wypożyczeń ${ }^{29}$ oraz prowadzonej dziennej statystyki wypożyczeń według płci mogła opracować materiał opublikowany pt. Dwadzieścia poczytnych książek $k^{30}$.

$\mathrm{Na}$ początku lat 30 . XX w. sieć warszawskich bibliotek publicznych dla dzieci powiększała się. Dlatego w 1936 r. dyrekcja Biblioteki Publicznej

25 H. Skrobiszewska, Pani Maria Gutry - ktoś, komu się udało, „Przegląd Biblioteczny” 1989, z. 4, s. 297-304.

26 B. Białkowska, K. Kuźmińska, Maria Gutry (1899-1988), [w:] Entuzjastki bibliotekarstwa..., s. 18.

27 E. Biegajówna, Maria Gutry, „Poradnik Bibliotekarza” 1989, nr 7-8-9, s. 61-62.

28 K. Kuźmińska, Maria Gutry (1899-1988), „Przegląd Biblioteczny” 1989, z. 4, s. 293-297.

29 Na kartach były notowane wypożyczone książki wraz z informacją, czy podobały się czytelnikowi, czy nie.

30 M. Gutry, B. Grosglikowa, Dwadzieścia poczytnych książek, Warszawa-Kraków 1933. 
m.st. Warszawy podjęła decyzję o utworzeniu osobnej Sekcji Bibliotek dla Dzieci. Jej kierownictwo powierzono właśnie Gutry. Był to moment znacznego rozszerzenia zakresu jej działalności. Sekcja zajmowała się nie tylko organizacją bibliotek dla dzieci na terenie miasta, pracami nad stworzeniem Muzeum Książki Dziecięcej, współpracą międzynarodową, ale - co istotne dla późniejszych, powojennych już prac Gutry - organizacją kursów i praktyk dla bibliotekarek dziecięcych. Przygotowanie odpowiedniej kadry dla tych placówek będzie dominantą w powojennej działalności M. Gutry. Do wybuchu wojny pozostanie organizatorką najpierw jednej placówki, następnie sieci bibliotek na terenie Warszawy. O sukcesie tych przedsięwzięć zadecydowała jej wiedza i wizja działania, entuzjazm, energia i konsekwencja.

Wojnę Gutry spędziła w Warszawie; brała udział w zabezpieczaniu zbiorów Biblioteki Publicznej m.st. Warszawy i Biblioteki Politechniki Warszawskiej, czynnie działała w konspiracji ${ }^{31}$, walczyła w powstaniu warszawskim ${ }^{32}$, a po jego upadku przeszła przez kilka obozów jenieckich. Dosłużyła się stopnia kapitana Armii Krajowej.

Do Warszawy wróciła już w listopadzie 1945 r. i ponownie objęła stanowisko kierowniczki Sekcji Bibliotek dla Dzieci. Od 1949 r. tworzyła analogiczną sekcję w Robotniczym Towarzystwie Przyjaciół Dzieci (RTPD). Trudno zrozumieć, dlaczego kapitan AK, uczestniczka powstania już w lutym 1954 r., a więc jeszcze przed pełnią postalinowskiej „odwilży” została zatrudniona w Centralnym Zarządzie Bibliotek Ministerstwa Kultury i Sztuki na stanowisku wizytatora do spraw bibliotek dla dzieci, w którym przepracowała 14 lat do momentu przejścia na emeryturę $\mathrm{w}$ grudniu $1968 \mathrm{r}$. W pracy ministerialnej można wskazać dwa główne kierunki jej działalności. Po pierwsze, były to prace nad ujednoliceniem ram organizacyjnych bibliotek publicznych dla dzieci - w 1957 r. opublikowano Wskazówki w sprawie organizacji bibliotek dla dzieci i księgozbiorów dla dzieci w publicznych bibliotekach powszech$n y c h^{33}$, których była autorką. Po drugie, było to przygotowanie specjalizacji wojewódzkich instruktorów czytelnictwa dziecięcego, niezbędne przy wzroście liczby bibliotek dla dzieci. W pamięci współpracowników została jednak jako niestrudzona organizatorka dorocznych seminariów, najpierw dla wszystkich bibliotekarzy dziecięcych a następnie dla instruktorów wojewódzkich.

\footnotetext{
31 M. Gutry nosiła pseudonim „Julia”, służyła w Komendzie Głównej AK - Oddział V (Dowodzenia i Łączności).

32 Zob. Muzeum Powstania Warszawskiego, Maria Gutry, [w:] Powstańcze biogramy, [online] https://www.1944.pl/powstancze-biogramy/maria-gutry,11146.html [dostęp 25.07.2019].

33 Wskazówki w sprawie organizacji bibliotek dla dzieci i księgozbiorów dla dzieci w publicznych bibliotekach powszechnych, [w:] Przepisy prawne dla bibliotek powszechnych, zebrał i oprac. T. Zarzębski, Warszawa 1965, s. 67-74. Wskazówki... stanowiły załącznik do Pisma Ministerstwa Kultury i Sztuki Centralnego Zarząu Bibliotek z dnia 20 lipca 1957 r. (Nr B-IV-3/22/57) wprowadzającego dokument w życie, tamże, s. 67.
} 
W programach seminariów kładziono nacisk na znajomość literatury dziecięcej $^{34}$. Organizowała także i prowadziła kursy bibliotekarstwa dziecięcego w ośrodku kształcenia bibliotekarzy w Jarocinie. O niezwykłej atmosferze jarocińskich kursów, wymaganiach stawianych uczestniczkom przez M. Gutry, pisały w swoich wspomnieniach H. Skrobiszewska i E. Biegajówna.

Doświadczenia w prowadzeniu jednej biblioteki a następnie sieci miejskiej Gutry wykorzystała po wojnie w skali ogólnopolskiej. Biblioteki publiczne dla dzieci w Polsce zawdzięczają jej nie tylko ramy organizacyjne, ale przede wszystkim wizję działalności, poczucie misji, odpowiedzialności za wychowanie młodych pokoleń.

M. Gutry nie założyła własnej rodziny, co niewątpliwie miało wpływ na jej pełną dyspozycyjność zawodową. Pozostawiła po sobie liczne publikacje, przed- i powojenne ${ }^{35}$. Wśród wielu odznaczeń najbardziej ceniła nadany jej przez dzieci Order Uśmiechu. Do końca życia utrzymywała kontakt z Biblioteką dla Dzieci nr V na warszawskiej Ochocie kontynuującą tradycje przedwojennej Biblioteki Wzorowej.

\section{Zofia Wędrychowska-Papuzińska (1904-1944) $)^{36}$}

Drugą ważną postacią warszawskiego bibliotekarstwa dziecięcego była Zofia Wędrychowska-Papuzińska. Kobieta, której krótkie życie i tragiczna śmierć z rąk okupantów przeszła do legendy. Jej postać znamy najpełniej ze wspomnień córki, Joanny Papuzińskiej.

Urodziła się w 1904 r. w Mińsku Mazowieckim, ale prawie całe swoje życie spędziła w Warszawie. Tu uczęszczała początkowo na tzw. pensję Panien

34 O pierwszych seminariach i ich programie pisała sama M. Gutry w tekście: Doroczne seminaria w sprawach czytelnictwa dziecięcego, organizowane przez Departament Pracy Kulturalno-Oświatowej i Bibliotek Min. Kultury i Sztuki, [w:] Kim jesteś Kopciuszku czyli o problemach współczesnej literatury dla dzieci i młodzieży, red. S. Aleksandrzak, Warszawa 1968, s. 294-298.

35 K. Kuźmińska, Bibliografia prac Marii Gutry, „Przegląd Biblioteczny” 1989, z. 4, s. 304307.

36 W różnych źródłach podawany jest inny rok urodzenia 1904 lub 1905. Ta druga data pojawia się w tekstach J. Papuzińskiej: Zofia Wędrychowska-Papuzińska (1905-1944), [w:] Entuzjastki bibliotekarstwa..., s. 47; Zofia Wedrychowska-Papuzińska (1905-1944). Wspomnienie córki, [w:] Żyja w naszej pamięci. Wspomnienia o pracownikach Biblioteki Publicznej m.st. Warszawy, Warszawa 2006, s. 133-138 oraz na tablicy upamiętniającej Wędrychowską-Papuzińską w Bibliotece Publicznej dla Dzieci nr 5 (obecnie ul. Grójecka 109). Rok 1904 został podany w biogramie autorstwa M. Gutry zamieszczonym w Stowniku pracowników książi polskiej, [red. I. Treichel], Warszawa 1972, s. 948; w innym wspomnieniu J. Papuzińskiej, Idee korczakowskie drogowskazem - Zofia Węrychowska-Papuzińska, [w:] Z ksiażka do ludzi, Warszawa 1992, Bibliotekarze Polscy we Wspomnieniach Współczesnych, t. 2, s. 81, oraz we wspomnieniu Aleksandry Witkowskiej, 25 rocznica śmierci Zofii Wędrychowskiej-Papuzińskiej, „Bibliotekarz” 1969, nr 6, s. 189-190. Jako rzeczywistą datę urodzin Wędrychowskiej-Papuzińskiej przyjmuję $1904 \mathrm{r}$. 
Jadwig $^{37}$ na Wiejskiej 5, a następnie na Państwowy Kurs Nauczycielski, gdzie pedagogami byli m.in. Władysław Spasowski i H. Radlińska ${ }^{38}$. Po maturze w 1923 r. podjęła pracę jako wychowawczyni i bibliotekarka w „Naszym Domu" ${ }^{39}$. Tu zetknęła się z kolejną wielką osobowością pedagogiczną tamtych lat - Januszem Korczakiem i przyjęła w swojej pracy idee wychowania korczakowskiego ${ }^{40}$. W latach 1926-1928 studiowała w Krakowie w Wyższej Szkole Pielęgniarskiej. W 1928 r. wyszła za mąż za Stanisława Papuzińskiego i w 1934 r., po kilku trudnych latach (m.in. związanych z pracą w zakładzie dla dzieci wykolejonych koło Częstochowy), rodzina Papuzińskich zamieszkała na warszawskiej Ochocie na ul. Mątwickiej. Tu Wędrychowska-Papuzińska spędziła kolejnych dziesięć lat, aż do śmierci w 1944 r.

Objęcie przez Wędrychowską kierownictwa Biblioteki Wzorowej, wówczas już Biblioteki dla Dzieci nr 1 wiązało się jednocześnie z podjęciem studiów na Studium Pracy Społeczno-Oświatowej WWP, gdzie kontynuowała naukę u znanej z wcześniejszych lat $\mathrm{H}$. Radlińskiej.

Pod kierownictwem Wędrychowskiej, wykorzystującej w pracy doświadczenia korczakowskie ${ }^{41}$, biblioteka rozwinęła działalność wśród dzieci, m.in. tworząc aktyw biblioteczny - samorząd dzieci, które włączały się w drobne prace biblioteczne. W bibliotece stosowała znane formy pracy jak np. opowiadanie baśni, przestawienia kukiełkowe, konkursy. W archiwum Biblioteki Publicznej m.st. Warszawy zachowała się opinia o Z. Wędrychowskiej, którą warto tutaj przytoczyć:

Ceniliśmy jej osobisty wpływ na dzieci, zmysł organizacyjny, bogactwo myśli i inicjatywy, podziwialiśmy jej niestrudzony ogrom wysiłku - na miarę zgoła niespotkanąa ${ }^{42}$.

Dobrze rozwijającą się działalność placówki przerwał wybuch wojny. Po kapitulacji Wędrychowska wróciła do biblioteki, która na szczęście nie ucierpiała podczas działań zbrojnych. Wokół siebie skupiała coraz większe grono dzieci, które traktowały bibliotekę jak drugi, a często i pierwszy, dom. Wędrychowska starała się, aby biblioteka była dla nich miejscem przyjaznym i bezpiecznym. Mimo trudnych warunków dzieci podejmowały różne działania, których opis

37 Pensja została założona w 1903 r. przez Jadwigę Kowalczykównę i Jadwigę Jawurkównę, zob. Szkoła na Wiejskiej, red. K. Kujawska i in., Warszawa 2007.

38 Radlińska była również nauczycielką na pensji panien Jadwig, gdzie uczyła historii Polski, tamże

39 „Nasz Dom” - zakład opiekuńczo-wychowawczy założony w Pruszkowie w 1919 r. przez Marynę Falską, od 1928 r. mieszczący się na warszawskich Bielanach, zob. Nasz Dom 1919-2019. Pedagogiki społeczne, miasto i dzieciństwo w praktyce Naszego Domu, red. nauk. M. Gołąb, Z. Sękowska, Warszawa 2019.

40 „Idee korczakowskie drogowskazem - Zofia Wędrychowska-Papuzińska” - tak swoje wspomnienie o matce zatytułowała J. Papuzińska, zob. taż, Idee korczakowskie..., s. 81.

41 Tamże, s. 83.

42 Cyt. za: A. Witkowska, 25 rocznica..., s. 189-190. 
znajduje się w zachowanym zeszycie protokołów zebrań Koła Stałych Czytelników i ocalałych czterech kartek zeszytu „Kronika Czytelni dla Dzieci nr 1 za rok 1941-1942"43. Oprócz działań typowo bibliotecznych - organizowanie konkursów, odczytów, wystaw, przedstawień, prowadzenia prac bieżących, Koło Stałych Czytelników podejmowało także prace społeczne, do których należało zbieranie książek czy organizowanie dla dzieci z przedszkola zabawy choinkowej i prezentów. Troszczono się o nie w sposób szczególny:

Przedszkolaki...O Boże! Takie, co może jedną choinkę przedwojenną pamiętają - może dwie, a wiele i żadnej. Za małe są aby te cudowne, kochane, dobre czasy w wolnej Ojczyźnie pamiętać! Jak za dotknięciem czarodziejskiej różdżki jedna myśl tryska z głów naszej starszyzny: Gwiazdka dla przedszkola musi być jak przedwojenna ${ }^{44}$.

Żywo zareagowano na prośbę Polskiego Czerwonego Krzyża dotyczącą zbierania zużytych biletów tramwajowych, za które można było dostać obiady. Przede wszystkim jednak jako nadrzędną traktowano sprawę wychowania czytelników: „niech się okaże, że nie możemy zdziczeć, chociaż jest wojna”" Jak napisała we wspomnieniu o Z. Wędrychowskiej Genowefa Rybicka:

niezwykły stosunek miała do dzieci. Darzyła je uczuciem, a poza tym miała talent do wnikania w ich sytuację, odczuwania wszelkich ich trosk. Nie podchodziła do nich szablonowo, była przyjacielem każdego z osobna, znała jego świat wewnętrzny. Wydawało się to u niej sztuką wrodzoną, intuicyjną... ${ }^{46}$.

Kiedy decyzją władz okupacyjnych w połowie 1942 r. biblioteki zostały zamknięte Wędrychowską skierowano do Biblioteki Głównej na ul. Koszykową, gdzie opiekowała się księgozbiorami nieczynnych placówek dla dzieci. Natomiast w swoim mieszkaniu udostępniała dzieciom książki z własnego i częściowo wyniesionego z biblioteki zbioru. Ostanie dwa lata jej życia (19421944) to przede wszystkim pomoc dzieciom, tak polskim jak i żydowskim, w ocaleniu ich dzieciństwa. Dom na Mątwickiej służył jako schronienie dla wielu osób. Ukrywały się w nim m.in. Stefania Wortman z matką i B. Groniowska z synem ${ }^{47}$.

Z. Wędrychowska-Papuzińska została rozstrzelana w ruinach getta w kwietniu 1944 r. Po wojnie nie zapomniano o niej, stąd na spotkaniu poświęconym jej pamięci zorganizowanym w 25 rocznicę śmierci wysunięto wniosek o nadanie

43 Biblioteka Publiczna dla Dzieci nr 5 Warszawa Ochota, Protokoły zebrań Koła Stałych Czytelników przy Bibliotece dla Dzieci Nr 1 rok 1940-1942, s. 57 rps; archiwum rodziny Papuzińskich, Kronika Czytelni dla Dzieci nr 1 rok 1941-1942, rps, s. 8.

44 Kronika Czytelni dla Dzieci nr 1 rok 1941-1942, s. 2. Zob. też. J. Papuzińska, Idee korczakowskie..., s. 85-86.

45 Protokoły zebrań Koła Stałych Czytelników przy Bibliotece dla dzieci Nr 1 rok 1940-1942 s. 6 , rps.

46 G. Rybicka, Zofia Wędrychowska, [w:] Wspomnienia o Władystawie Spasowskim, pod red. M. Szulkina, Warszawa 1961, s. 236.

47 Papuzińska J., Idee korczakowskie..., s. 86. 
jej imienia Bibliotece Dziecięcej nr 5, która wówczas mieściła się przy ul. Częstochowskiej $25^{48}$. Ostatecznie, po wieloletnich staraniach, patronką kierowanej przez siebie placówki Wędrychowska została 1 X 1994 r. (50 lat po śmierci).

We wspomnieniu o niej Aleksandra Witkowska napisała: „Obdarzona talentem pedagogicznym i wielkim zamiłowaniem do pracy z książką, potrafiła umiejętnie kierować zainteresowaniami dzieci" ${ }^{49}$. G. Rybicka swoje wspomnienia podsumowała następująco: „Dawała radość ludziom, z którymi obcowała, zwłaszcza dzieciom” ${ }^{50}$. Jest to, jak napisała J. Papuzińska: „postać obrosła legendą, skonstruowana nie tylko z faktów, ale również z wyobraźni, pragnień i dążeń osób ją tworzących"51.

\section{Sława Łabanowska (1926-2004)}

S. Łabanowska to postać najmniej znana ze wszystkich trzech prezentowanych bibliotekarek. Całe swoje zawodowe, bardzo długie życie poświęciła pracy w jednej placówce. Można powiedzieć, że toczyło się ono „w cieniu gwiazd". Była niepozorna ciałem, wielka duchem; była bibliotekarką, pedagogiem, wychowawcą pokoleń czytelników. Przez ponad 40 lat, co dziś wydaje się nieprawdopodobne, była kierowniczką jednej placówki. Pracę w niej rozpoczęła 1 XII 1946, od stycznia 1947 już na stanowisku kierowniczym, które piastowała do 10 VIII 1990 r. Następnie przez kolejne 11 lat pracowała, wciąż w tej samej bibliotece, na pół etatu, a od 2001 r. do śmierci w 2004 r. służyła swoją wiedzą i doświadczeniem jako wolontariuszka. Należała do pierwszej powojennej kadry zawodowej, która odbudowywała warszawskie bibliotekarstwo po zniszczeniach wojennych, a następnie przeprowadzała je przez trudne dziesięciolecia okresu PRL-u. We wspomnieniach zapisała się jako osoba skromna, łagodna, miła, serdeczna i życzliwa. Oddana sercem dzieciom i młodzieży. Niewątpliwie bibliotekarstwo było jej pasją.

Łabanowska urodziła się w Sokółce, dzieciństwo spędziła w Grodnie, ale jej miastem stała się ostatecznie Warszawa, w której przeżyła wojnę, powstanie, i do której powróciła po powojennej tułaczce. Jesienią 1946 r. rozpoczęła studia na wydziale socjologii UW oraz kurs dla bibliotekarek bibliotek dziecięcych organizowany przez Bibliotekę Publiczną m.st. Warszawy. Była, podobnie jak jej poprzedniczki, bardzo aktywna, pisała i publikowała na łamach czasopism fachowych, takich jak: „Bibliotekarz”, „Poradnik Bibliotekarza”, „Nowa Szkoła”. Opracowała rozdziały do poradnika metodycznego $W$ bibliotece dla

\footnotetext{
48 A. Witkowska, 25 rocznica..., s. 190.

49 Tamże.

50 G. Rybicka, Zofia Wędrychowska..., s. 248.

51 J. Papuzińska, Idee korczakowskie..., s. 81.
} 
dzieci. Były to: Praca z czytelnikiem indywidualnym, Przysposobienie czytelnicze, Opowiadanie, Konkursy, Wystawki, Kalendarz historyczny aktualności, Wspótpraca ze szkołami, Wspótpraca z instytucjami i organizacjami ${ }^{52}$. W latach 60. XX w. wykładała bibliotekarstwo dziecięce, metodykę pracy z czytelnikiem na kursach Państwowego Ośrodka Kształcenia Bibliotekarzy w Jarocinie. Od stycznia 1969 r. rozpoczęła organizowanie w bibliotece kursów wiedzy o Warszawie we współpracy z TPW. Wychowała kilka pokoleń miłośników Warszawy, dla których organizowała konkursy wiedzy o mieście i wycieczki.

$\mathrm{W}$ trudnych latach 50 . Łabanowska ratowała książki wycofywane $\mathrm{z}$ bibliotek na podstawie decyzji władz. Przenoszone były do magazynu i prawdopodobnie udostępniane najbardziej zaufanym czytelnikom ${ }^{53}$. Dużo trudniejszym zadaniem było umiejętne przekształcanie narzucanych odgórnie socjalistycznych tematów prac $\mathrm{w}$ bibliotece tak, aby z jednej strony ich realizacja była zgodna z ogólnymi wytycznymi, a jednocześnie jak najmniej nacechowana ideologicznie. W ten sposób np. osiągnięcia, dorobek ZSRR pokazywany był dzieciom poprzez rosyjskie baśnie, przyrodę, krajobrazy ${ }^{54}$. Pani Sława umiała opowiadać baśnie, do jednej z ulubionych należał Konik garbusek Piotra Jerszowa.

Pracowała z trudną młodzieżą, do czego przydała jej się wiedza zdobyta podczas studiów. W kręgu jej zainteresowań pozostawały też dzieci chore i niepełnosprawne, m.in. ze szkoły specjalnej na ul. Radomskiej, którym opowiadała baśnie, głośno czytała, przeprowadzała konkursy. Współpracowała z Poradnią Wychowawczo-Społeczną TPD. Doskonale organizowała współpracę ze szkołami, przygotowując dla dzieci zajęcia z przysposobienia czytelniczego i spotkania nauczycieli. Prowadziła też zajęcia dla studentów wydziału pedagogicznego, bibliotekoznawstwa UW, warszawskiej Akademii Pedagogiki Specjalnej (wcześniej Instytutu Pedagogiki Specjalnej). Niezmiernie trudno jest przedstawić cały dorobek zawodowy Łabanowskiej, przede wszystkim ze względu na wiele lat pracy i podejmowane przez nią różnorodne działania. Przede wszystkim jednak była entuzjastką bibliotekarstwa dziecięcego:

starała się poznać czytelnika, zaprzyjaźnić się z nim, szukała dla każdego nie tylko zachęcających do czytania książek, ale stwarzała każdemu możliwość rozwoju emocjonalnego oraz intelektualnego ${ }^{55}$.

Podobnie jak Maria Gutry, S. Łabanowska nie założyła rodziny, być może dlatego mogła poświęcić swój czas w całości pracy zawodowej i społecznej.

$52 \quad W$ bibliotece dla dzieci. Poradnik metodyczny, red. I. Nieczowa, wyd. 1, Warszawa 1965; wyd. 2, 1972.

53 Sama otrzymałam od S. Łabanowskiej wycofany w ten sposób egzemplarz Małego lorda Frances Hodgson Burnett.

54 Informacje na podstawie rozmów ze S. Łabanowską.

55 B. Białkowska, Stawa Labanowska (1926-2004), [w:] Żyją w naszej pamięci..., s. 263. 
Co łączy opisane wyżej postacie? - jedna biblioteka i pełnione stanowisko. Na pewno też Warszawa, choć tylko M. Gutry była warszawianką z urodzenia. Wszystkie panie pisały - Gutry i Łabanowska artykuły badawcze i fachowe, Wędrychowska-Papuzińska teksty literackie i recenzje książek dla dziecis ${ }^{56}$. M. Gutry i Z. Wędrychowską łączyła też osoba H. Radlińskiej i Studium Pracy Społeczno-Oświatowej WWP. Wszystkie w swoim życiu kierowały się pasją, służbą, poświęceniem, miłością do dzieci (także z trudnych środowisk, chorych - Z. Wędrychowska-Papuzińska, S. Łabanowska) i książek. Cechowała je samodzielność, konsekwencja w działaniu, podejmowanie różnorodnych wyzwań. Co dzieliło kierowniczki Biblioteki Wzorowej? - chyba tylko status rodzinny. Jedynie Wędrychowska założyła rodzinę.

\section{$* * *$}

Na koniec kilka wspomnień natury osobistej. Nie pisałabym o warszawskiej placówce i jej trzech kierowniczkach, gdyby nie studencki staż, jaki odbyłam jesienią 1987 r. w Bibliotece dla Dzieci nr V na Ochocie mieszczącej się wówczas przy ul. Grójeckiej 81/87 (róg ul. Banacha). Cztery tygodnie praktyk w niej spędzone zaważyły na moim zawodowym życiu. W konsekwencji o tej placówce nie tylko napisałam pracę magisterską ${ }^{57}$, ale przede wszystkim poznałam S. Łabanowską, już wówczas legendarną postać wśród warszawskich bibliotekarek dziecięcych.

Przychodząc do biblioteki miałam duże mniemanie o mojej wiedzy bibliotekoznawczej, myślałam, że zrewolucjonizuję pracę placówki. Tymczasem mój staż polegał przede wszystkim na czytaniu książek dla dzieci i młodzieży. Pani Sława podkreślała, że nie można być dobrym bibliotekarzem dziecięcym nie znając literatury, zasobów biblioteki. Bez tej wiedzy nie sposób polecić czytelnikowi książek. Podsuwała mi coraz to nowe tytuły, stosik rósł, ja czytałam, czytałam, i podziwiałam niezwykłą umiejętność pani Sławy nawiązywania kontaktu z przychodzącymi dziećmi, sposób rozmowy, uśmiech, życzliwość. Drobna, siwa, niepozorna, wzbudzała szacunek. Rzadko podnosiła głos. Drugą postacią, którą dane mi było wówczas poznać była również legendarna, już nie tylko w kręgu bibliotek dziecięcych Warszawy ale całej Polski, M. Gutry. W listopadzie 1987 r. biblioteka świętowała 60. rocznicę działalności, na uroczystości była zaproszona jej twórczyni, pierwsza przedwojenna kierowniczka - właśnie M. Gutry. Jest więc zrozumiałe, że zaproszenie na jubileusz i możliwość udziału w nim potraktowałam jako wyróżnienie.

$56 \quad$ Wspomina o tym J. Papuzińska w Idee korczakowskie..., s. 84.

57 G. Lewandowicz, Biblioteka Publiczna dla Dzieci i Młodzieży nr Vw Warszawie, Warszawa 1988, praca magisterska napisana pod kierunkiem prof. dr hab. B. Bieńkowskiej, mszp. przechowywany w Bibliotece Wydziału Dziennikarstwa, Informacji i Bibliologii UW. 


\section{Podsumowanie}

Niewątpliwie, bez trzech przywołanych tutaj kobiet nie byłoby Biblioteki Wzorowej, nie tylko jako instytucji, ale przede wszystkim, dla wielu pokoleń czytelników (na długo przed definicją Raya Oldenburga) słynnego dziś „trzeciego miejsca", za które można uznać tę placówkę ${ }^{58}$. M. Gutry, Z. Wędrychowska-Papuzińska i S. Łabanowska stworzyły z biblioteki właśnie miejsce spotkania dziecka z książką, z dorosłym, z innymi dziećmi, ale przede wszystkim z samym sobą. Bez nich, bez ich pracy, z pewnością nie byłoby sieci bibliotek dla dzieci w Warszawie, w Polsce, nie byłoby legendy ,piątki” i, co najważniejsze, zastępów wiernych czytelników.

\section{Bibliografia}

Białkowska B., Sława Łabanowska (1926-2004), [w:] Żyja w naszej pamięci. Wspomnienia o pracownikach Biblioteki Publicznej m.st. Warszawy, Warszawa 2006, s. 261-264. Białkowska B., Kuźmińska K., Maria Gutry (1899-1988), [w:] Entuzjastki bibliotekarstwa dziecięcego, [red. t. B. Białkowska, przy współudz. W. Wasilewskiej], Warszawa 1999, s. 11-24.

Biblioteki dla dzieci w Polsce, Warszawa 1934.

Biegajówna E., Maria Gutry, „Poradnik Bibliotekarza” 1989, nr 7/8/9, s. 61-62.

Boelt K., Open libraries in Aalborg - a great success, „Scandinavian Library Quarterly" 2015, Vol. 48, nr 1-2, [online] http:/www.slq.nu/indexe9ab.html?article=volume-48-no-1-2-2015-19 [dostęp 12.06.2020].

Dzieci, młodziez - Internet - biblioteka. Wytyczne IFLA Sekcji Bibliotek dla Dzieci i Młodzieży, red. G. Lewandowicz-Nosal, E.B. Zybert, Warszawa 2009.

Filipkowska-Szemplińska J., Gutry M., Katalog biblioteki wzorowej dla dzieci i młodzie$\dot{z} y$, z przedmową H. Radlińskiej, Warszawa 1927,

Gutry M., Biblioteka wzorowa dla dzieci m.st. Warszawy, [w:] Biblioteki dla dzieci w Polsce, Warszawa 1934, s. 9-14.

Gutry M., Doroczne seminaria w sprawach czytelnictwa dziecięcego, organizowane przez Departament Pracy Kulturalno-Oświatowej i Bibliotek Min. Kultury i Sztuki, [w:] Kim jesteś Kopciuszku czyli o problemach wspótczesnej literatury dla dzieci i młodzieży, red. S. Aleksandrzak, Warszawa 1968, s. 294-298.

Gutry M., Grosglikowa B., Dwadzieścia poczytnych ksiązek, Warszawa-Kraków 1933.

Johannsen C.G., Staffless libraries - recent Danish public libraries experiences, „New Library World” 2012, Vol. 113, nr 7/8, s. 333-342.

Kuźmińska K., Maria Gutry (1899-1988), „Przegląd Biblioteczny” 1989, z. 4, s. 293-297.

58 R. Oldenburg, The great good place: cafés, coffee shops, community centers, beauty parlors, general stores, bars, hangouts, and how they get you through the day, New York 1989. 
Kuźmińska K., Bibliografia prac Marii Gutry, „Przegląd Biblioteczny” 1989, z. 4, s. 304307.

Langer H., Obraz Biblioteki Wzorowej na lamach periodyków Biblioteki Publicznej m.st. Warszawy (1929-1939), „Bibliotheca Nostra” 2016, nr 3(45), s. 73-85.

Lewandowicz G., Biblioteka Publiczna dla Dzieci i Młodzieży nr Vw Warszawie, Warszawa 1988, praca magisterska napisana pod kierunkiem prof. dr hab. B. Bieńkowskiej, mszp. przechowywany w Bibliotece Wydziału Dziennikarstwa, Informacji i Bibliologii UW.

Lewandowicz-Nosal G., Biblioteka dla dzieci: miejsce magiczne, [w:] Ocalone królestwo. Twórczość dla dzieci - perspektywy badawcze - problemy animacji, red. nauk. G. Leszczyński, D. Świerczyńska-Jelonek, M. Zając, Warszawa 2009, s. 315-325.

Lewandowicz-Nosal G., Public libraries for children in Poland 1918-1939 - assumptions and reality, „Z Badań nad Książką i Księgozbiorami Historycznymi” 2019-2020, t. specjalny: Dla Niepodległej, red. nauk. tomu M. Ochmański, D. Pietrzkiewicz, J. Puchalski, s. 53-72.

Maria Gutry, [w:] Powstańcze biogramy, [online] https://www.1944.pl/powstancze-biogramy/maria-gutry,11146.html [dostęp 25.07.2019].

Nasz Dom 1919-2019. Pedagogiki spoleczne, miasto i dzieciństwo w praktyce Naszego Domu, red. nauk. M. Gołąb, Z. Sękowska, Warszawa 2019.

Oldenburg R., The great good place: cafés, coffee shops, community centers, beauty parlors, general stores, bars, hangouts, and how they get you through the day, New York 1989.

Papuzińska J., Biblioteka [fragmenty wspomnień z książki Darowane kreski, Łódź 2002], „Guliwer” 2005, nr 3, s. 33-35.

Papuzińska J., Biblioteki $w$ stużbie dzieciom, [w:] Biblioteka $w$ otoczeniu społecznym, pod red. B. Zybert, Warszawa 2000, s. 52-77.

Papuzińska J., Darowane kreski, wyd. 2, Łódź 2002.

Papuzińska J., Idee korczakowskie drogowskazem - Zofia Wędrychowska-Papuzińska, [w:] Z książka do ludzi, Warszawa 1992, Bibliotekarze Polscy we Wspomnieniach Współczesnych, t. 2, s. 81-88.

Papuzińska J., Zofia Wędrychowska-Papuzińska (1905-1944). Wspomnienie córki, [w:] Żyja w naszej pamięci. Wspomnienia o pracownikach Biblioteki Publicznej m. st. Warszawy, Warszawa 2006, s. 133-138, przedruk z Entuzjastki bibliotekarstwa dziecięcego, [red. t. B. Białkowska, przy współudz. W. Wasilewskiej], Warszawa 1999.

Pęska L., Felicja Neubert (1904-1978), [w:] Entuzjastki bibliotekarstwa dziecięcego, [red. t. B. Białkowska, przy współudz. W. Wasilewskiej], Warszawa 1999, s. 63-70.

Rybicka G., Zofia Wędrychowska, [w :] Wspomnienia o Władysławie Spasowskim, pod red. M. Szulkina, Warszawa 1961, s. 231-248.

Skrobiszewska H., Pani Maria Gutry - ktoś, komu się udało, „Przegląd Biblioteczny” 1989, z. 4, s. 297-304.

Szkoła na Wiejskiej, red. K. Kujawska i in., Warszawa 2007. 
Umerska Z., Pani Staweczka (1926-2004), „Poradnik Bibliotekarza” 2004, nr 7-8, s. 46-47. $W$ bibliotece dla dzieci. Poradnik metodyczny, red. I. Nieczowa, wyd. 1, Warszawa 1965; wyd. 2, 1972.

Wasilewska E., Stawa Zofia Labanowska (1926-2004), [w:] Bibliotekarze warszawscy zmarli w latach 1997-2007, red. tomu M. Lenartowicz, Warszawa 2010, s. 126-136.

Witkowska A., 25 rocznica śmierci Zofii Wędrychowskiej-Papuzińskiej, „Bibliotekarz” 1969, nr 6, s. 189-190.

Wskazówki w sprawie organizacji bibliotek dla dzieci i księgozbiorów dla dzieci w publicznych bibliotekach powszechnych, [w:] Przepisy prawne dla bibliotek powszechnych, zebrał i oprac. T. Zarzębski, Warszawa 1965, s. 67-74.

Zając M., Biblioteki i młodzież: przyjaciele, wrogowie, nieznajomi?, [w:] Biblioteka w otoczeniu społecznym, pod red. B. Zybert, Warszawa 2000, s. 78-95. 